\title{
Inward Investment, Employment and Government Policies in Wales
}

\author{
MARK COOK*, GRAHAME FALLON** \\ * Wolverhampton Business School, Wolverhampton University, Wulfruna Street, \\ Wolverhampton, WV1 1LY. Email: mark.cook@wlv.ac.uk \\ **Brunel Business School, Brunel University, Uxbridge, London UB8 3PH. Email: \\ grahame.fallon@brunel.ac.uk
}

Key words:

Types of inward investment, countries of origin, capital investment, employment effects, government policy implications, peripheral regions, developed market economies, Wales

\begin{abstract}
This empirical paper examines the links between multinational enterprises' countries of origin, types of inbound foreign direct investment, related capital investment levels and the resultant effects on regional employment in Wales, a peripheral region of the UK.

Longitudinal, official data is used to examine the relationships between these variables, making use of statistical techniques. The findings are used to make recommendations for inward investment policy development in Wales, focusing on the targeting of IFDI from those countries of origin whose MNEs appear likely to contribute most to the future creation and safeguarding of regional employment.
\end{abstract}




\section{INTRODUCTION}

The purpose of this paper is to add to the research literature on the regional employment effects of inbound FDI (IFDI) in developed market economies such as the United Kingdom (the UK), and the associated challenges for government policy makers. Relatively few studies have examined the effects of IFDI on regional employment, which the existing evidence suggests can be positive or negative overall (Crino, 2009; Marelli et al, 2014). These effects vary between more economically developed 'core' and less developed 'peripheral' regions, with the former tending to be far more attractive to IFDI (Bailey and

Driffield, 2002). Thus their existing advantages over peripheral regions will be reinforced by the production structure- and employment-enhancing effects of IFDI, unless policy makers act to make the latter more appealing to potential inward investors (Kottaridi, 2005;

Loewendahl, 2001).

Multinational enterprises' (MNEs') countries of origin, the types of IFDI that they deploy, and their associated capital investment levels have an important role to play in determining the employment effects of foreign investment in peripheral regions (Williams, 2003; Jones and Wren, 2004). Yet, there is little existing research into the links between these factors and the ensuing impact on the regional creation and safeguarding of jobs. Scholarly research into the resultant implications for government policy makers is also relatively underdeveloped (Thomas and Grosse, 2001).

The present study seeks to fill the resultant gap in the literature, by examining the employment impact of IFDI in Wales, one of the UK's peripheral regions (Phelps et al, 2003; Morgan, 2007). Its major contribution to the literature consists of an empirical 
analysis that explores the linkages between countries of origin, types of IFDI-related capital investment levels and the resultant employment effects in the Welsh context. This constitutes a valuable area of new research, owing to the critical importance assigned by governments (in Wales, the UK and beyond) to inward investment promotion as a means of addressing the problem of falling industrial employment in peripheral regions (Dawley, 2007; Almond et al, 2015). In contrast, however the targeting of MNEs' countries of origin for inward investment promotion tends to be relatively neglected by government policy makers (Young et al, 1994; Driffield and Munday, 2000).

The following section of the paper develops a conceptual framework based on a review of the existing literature relating to IFDI, employment and government policies in peripheral regions, such as Wales. The paper then explores Wales' recent record in attracting IFDI, together with the resultant employment effects. Statistical analysis is next used to examine the relationships between Welsh inward investors' countries of origin, the types of IFDI that they undertake, their IFDI- related capital investments, and the resultant creation and safeguarding of jobs in Wales, drawing on official, longitudinal data gathered from 1983 to March 2010 from UK and Welsh Assembly Government (WAG) sources. The findings are used to make recommendations for future inward investment policy development in Wales, focusing on the targeting of IFDI from countries of origin whose MNEs appear likely to contribute most to the future creation and safeguarding of regional employment. Some areas for future related research are also suggested. 


\section{CONCEPTUAL FRAMEWORK}

IFDI and employment effects in core and peripheral regions

Globalisation and economic integration amongst European Union (EU) and European Economic Area (EEA) member states has helped to create and maintain a 'core-periphery divide' between more and less economically developed regions (Krugman, 1991; Porter, 2003), corresponding to the 'North-South divide' in the UK (Rowthorn, 2010). IFDI has the potential to boost employment in both types of region (Navaretti and Venables, 2004; Crino, 2009), by means of the creation and safeguarding of jobs in wholly owned subsidiaries (WOS) and joint ventures (JVs), and the promotion of indirect employment in domestically owned businesses (Driffield, 1999; Girma et al, 2001). Core regions are generally more attractive to IFDI, however, owing to the allure of more highly developed regional markets, greater access to human and knowhow capital and greater availability of agglomeration economies (Guimaraes et al, 2000; Bailey and Driffield, 2002).

Government policy makers in peripheral UK regions, such as Wales have nonetheless attempted to reduce the core-periphery divide and mitigate structural unemployment by drawing in IFDI (Thomas, 1996; Driffield and Taylor, 2000). Yet although the indirect employment supported by each foreign subsidiary job is higher than for domestically owned businesses, total employment per pound of output is generally lower in peripheral regions (Brand et al, 2000). IFDI can also crowd out domestic investment in such regions, leading to negative indirect employment effects (De Backer and Sleuwaegen, 2003; Driffield and Hughes, 2003). These effects may be more marked if geographically concentrated IFDI inflows increase peripheral regions' dependence on single sources of 
employment, resulting in vulnerability to MNEs' future disinvestment or withdrawal decisions (Dawley, 2007).

IFDI countries of origin, types of IFDI and related capital investment

Countries of origin play a substantial role in determining the types of IFDI that MNE decision makers are willing to undertake in core and peripheral regions (Grosse and Trevino, 1996; Lipsey, 2004). These types of IFDI are influenced by the characteristics of home country culture and the cultural distances between their home and target countries (Makino and Neupert, 2000; Tihanyi et al, 2005). Less risky, wholly owned subsidiaries and joint ventures may well be preferred to riskier mergers and acquisitions (M\&As) where MNEs' home country levels of uncertainty-avoidance and cultural distances from chosen foreign locations are high (Brouthers and Brouthers, 2003; Reus and Lamont, 2009). For example, Japanese MNEs (coming from a high uncertainty avoidance culture), may be expected to avoid M\&As when investing direct in (culturally distant) European regions (such as Wales), whilst US and European MNEs (for which neither condition applies) would be prepared to consider them more readily (Yamawaki, 1994).

The types of IFDI chosen by MNEs from differing countries of origin result in varying consequences for job creation and safeguarding in peripheral regions such as Wales (McDonald et al, 2003; Pavlinek, 2004). New and expansionary projects are most likely to create the most positive direct employment effects, in the short term at least, by adding immediately to regional productive capacity, although their impact upon domestically-owned firms may offset these benefits (Williams, 2003). JVs may, however lead either to the creation of additional (employment boosting) productive capacity, or merely to (employment 
neutral) contractual agreements with regional partner firms (Dunning, 2000). M\&As may produce positive or negative employment effects, depending on the range of functions retained in merged organisations and the resultant impact on the demand for regional inputs (Ashcroft and Love, 1993). The net employment benefits resulting from JVs and M\&As may, however be greater in the long term, when the spillover effects that they create in host regions by stimulating heightened productivity, competition and knowledge flows have the chance to take full effect (Accolley, 2003; Navaretti and Venables, 2004).

The capital investment levels associated with inward investment often depend on the types of IFDI committed to particular regions (Hejazi and Pauly, 2003). Capital commitment will typically be greater where MNEs create or expand WOS abroad (through new or expansionary IFDI or M\&A), rather than choosing the JV route (Reuer and Leiblein, 2000). The resultant benefits for regional employment can be extremely variable, however, since the lion's share of such investments may be concentrated in a small number of large IFDI projects, where project-job intensity can be relatively low (Jones and Wren, 2004). Thus attracting large projects with high levels of capital investment may not necessarily maximise the creation or safeguarding of IFDI-related employment in peripheral regions such as Wales.

\section{Government inward investment policy}

Government policymakers in developed countries often place considerable emphasis on the contribution that IFDI can make to economic development and employment, resulting in the singling out of inward investment promotion as a national and regional priority (Brown and Raines, 2000; Lovering, 2003). The promotion of countries and regions to existing and 
potential inward investors varies markedly from place to place (Halkier et al, 2002), yet common themes nonetheless occur. Low labour costs, high productivity levels, tax breaks and other financial incentives are frequently used to draw in IFDI at the national and regional levels (Loewendahl, 2001; Lim, 2008), along with high-technology clusters, and universityindustry linkages in some cases (Adams et al, 2003; Blomström, et al, 2003).

Inward investment targeting by governments and inward investment agencies focuses more frequently on attracting IFDI from prioritised industrial sectors than from particular countries (Munday et al, 2009; Harding and Javorcik, 2011). Effective country of origin targeting, nonetheless has a potentially major contribution to make (Miškinis and Byrka, 2014) to the maximisation of IFDI and the related employment benefits, since these can vary considerably between MNEs from different home countries (Williams, 2003; Jones and Wren, 2004). However, there is little evidence that the UK or Welsh governments have been paying active attention to country of origin issues when determining which foreign- based MNEs to attract to Wales (MacKinnon and Phelps, 2001; Welsh Affairs Committee, 2012).

\section{IFDI IN WALES AND RELATED EMPLOYMENT EFFECTS}

Relative strengths and weaknesses of Wales' economy and institutions

The persistence of the UK's 'North-South divide' (Rowthorn, 2010) is reflected in the strengths and weaknesses of Wales' domestic economy and institutions (compared with other core and peripheral regions and the UK as a whole), resulting in potentially important 
influences on MNEs' willingness to commit IFDI and to create and safeguard jobs in Wales (Evans et al, 2008; Munday et al, 2009).

Regarding the Welsh economy, Table 1 shows that the size of its domestic market is relatively small, in population and gross value added terms, whilst recent reports (UKTI, 2015; Welsh Affairs Committee, 2012) also indicate that the region suffers from relative infrastructural weaknesses. All of these factors have the potential to deter market-seeking IFDI from being committed to Wales, despite the fact that exporting is relatively prominent amongst Welsh businesses, aided by the access that UK location gives them to the wider UK and Single European markets (Cardiff Business School, 2012; Welsh Affairs Committee, 2012). The table also shows that Wales enjoys relatively low labour costs and an abundant labour supply, resulting in a potential appeal to efficiency-seeking inward investors.

However, this appeal may be offset by the region's relatively poor productive efficiency and skill shortages in some key sectors (Evans et al, 2008; Welsh Affairs Committee, 2012). Wales' potential appeal to strategic asset-seeking IFDI also appears to be limited (despite the presence of established high-technology clusters, and university-industry links), owing to a shortfall in the numbers of new science-based, domestic businesses with which inward investors could work (BIS, 2011 and 2013; ONS, 2011; Welsh Affairs Committee, 2012).

Table 1 here

Recent institutional changes, including the establishment of the Welsh Assembly Government (WAG) in 2006 could, in theory have added to Wales' IFDI appeal (McGregor and Swales, 2005), by providing it with greater freedom of action regarding its inward 
investment support mechanisms and policies. In practice, however marketing, branding and promotional losses, associated with the abolition of the former Welsh Development Agency (Welsh Affairs Committee, 2012) and the closure of International Business Wales, appear to have damaged Wales' ability to compete effectively for IFDI (Evans et al, 2008: FDI Markets, 2012).

Regional selective assistance for inward investors is still relatively generous in parts of Wales (as Table 1 shows). However, the influence of government support for inward investment may now be waning, as traditional approaches such as investment tax breaks and grants (Loewendahl, 2001) appear to be becoming less effective in attracting IFDI away from rival locations such as Ireland (Cardiff Business School, 2012). Wales has also failed to develop a consistent strategy for the targeting of IFDI from promising sectors and countries of origin, resulting in further limits to its competitiveness as an IFDI destination (Welsh Affairs Committee, 2012; Cardiff City Council, 2013).

Implications for attraction of IFDI to Wales

Wales was relatively attractive to inward investment during the late nineteen eighties and nineteen nineties, enabling it to draw in a greater share of IFDI than any other UK region, apart from London, the South East and Scotland (Evans et al, 2008; Munday et al, 2009). There has since been a relative decline in the attractiveness of Wales to IFDI, however (Evans et al, 2008; Ramsay, 2012), reflected in its slide from second to ninth placed UK peripheral region (in new IFDI project terms) between 2003 and 2010 (see Table 2). There has also been a fall in Wales' share of the UK's IFDI-related jobs, from $11.8 \%$ in 1992 to only 5.6\% by 2005 (Welsh Affairs Committee, 2012, p.8). A total of 171 foreign-owned sites 
were closed in Wales between 1998 and 2008, resulting in the loss of 31,000 jobs, predominantly in the manufacturing sector.

Table 2 here

New inward investment flows into Wales are now recovering, taking the region upwards to fourth place in the UK's peripheral regional rankings for IFDI by 2011-12 (Cardiff Business School, 2012; UKTI, 2015). Wales still remains firmly anchored in the lower half of the regional rankings, however in terms of jobs created and safeguarded by IFDI (Ernst and Young, 2013).

\section{RESEARCH METHODS}

The aim of this paper is to examine the linkages between MNEs' countries of origin, the types of IFDI that they utilise (new, expansionary, acquisition and JVs), their IFDI-related capital investment levels and the resultant effects on the creation and safeguarding of employment in Wales. The empirical research underlying this study has been designed to answer the following research questions (RQ1-3 inclusive), developed from the existing literature (including Brand et al, 2000; Evans et al, 2008 and Jones and Wren, 2004):-

RQ1- What is the relationship between MNEs' countries of origin, types of IFDI and the resultant creation and safeguarding of jobs in Wales?

RQ2- What is the relationship between IFDI-related capital investment and the resultant creation and safeguarding of jobs in Wales? 
RQ3- What are the consequential implications for inward investment policy development in Wales and more specifically for the targeting of IFDI from particular countries of origin?

Use has been made of longitudinal data drawn from a range of official, published sources (including a Welsh Assembly Government (WAG) database for the period 1983-2010) in carrying out the underlying empirical study. Not all IFDI projects committed to Wales are the result of activity by WAG, yet it nonetheless collects data on all known, new, expansionary, M\&A and JV IFDI received. These data are published in project terms, by capital expenditure and in terms of jobs, the latter being separated into 'new' and 'safeguarded jobs'. New jobs are defined as the total number of new, permanent, paid, full time jobs that MNEs expect to create through IFDI over the three years after their initial investments, whilst jobs safeguarded are defined as permanent, paid, full time jobs which would have been at risk of being lost without additional direct investments in MNEs' UK operations (UKTI, 2015).

There is, of course a risk that some expected job creation or safeguarding following IFDI may never materialise (Scottish Government, 2000), resulting in overestimation of the resultant regional employment benefits. The WAG data also fail to reveal how far IFDI-related jobs are filled by expatriate or extra-regional labour, rather than by members of the established workforce in Wales.

Turning to the statistical analysis used in the paper, descriptive statistics were used in estimating Tables 1-4 inclusive, facilitating a discussion of the economic characteristics of Wales, its recent inward investment record, and leading national contributors to its IFDI, 
related employment effects and capital expenditure levels. This provided a useful context for the remainder of the study.

Cross tabulation analysis was then used in estimating Tables 5-8, where we categorised our raw data into large and small projects by countries of origin, based upon the quantity of jobs created or safeguarded by IFDI in Wales. ${ }^{\mathrm{i}}$ The number of investment projects was totalled for each year and for each country in turn, and these were then grouped into 4 categories (from low to high numbers of projects for new and safeguarded jobs). The joint distribution of the values of the dependent and independent variables was then estimated, and any data having a zero return in the data base were excluded. The results reported in the tables correspond to the estimated Pearson Chi Squared values, with greater values indicating more significant relationships between dependent and independent variables (Garson, 2013; McCormick and Salcedo, 2015)

When estimating Tables 9-12, use was made of correlation analysis, in order to determine the presence or absence of a linear relationship between IFDI-related capital expenditure, countries of origin and employment effects in Wales. We adopted this approach because raw data were available, in the form of monetary values for the actual capital expenditure involved in each one of the inward investment projects. Figures representing the expected numbers of new jobs created and safeguarded for each project were also available. ${ }^{\text {ii }}$ The resultant findings represent the correlation coefficients estimated using Pearson correlation coefficients and two-tailed significance tests, with significance levels being noted in the tables. To improve the validity of the results, we excluded any data which had a zero in the data base, whilst the data were also tested for normality ${ }^{\mathrm{iii}}$ with any outliers being removed (Ghasemi and Zahadias, 2012; Rose et al., 2015).

Comment [g1]: Response to reviewer, new Question (v): Query as to how can safeguarded jobs be associated with
investments now addressed in new investments now addressed in new
footnote to this page (footnote 1 , below)
Comment [g2]: Response to reviewer, new Question (ii): The findings reported in Tables 5-8 inclusive have now been revised for the sake of greater clarity, with use now being made of Pearson Chi Squared Values throughout the tables. The final sentence of page 9 para 1 has been modified to reflect this change. (Please see revised tables for confirmation).
Comment [g3]: Response to reviewer, new Question (iv): A new footnote (footnote 3 ) has now been added to this page explaining the process that we used to test for normality (please see below) 


\section{FINDINGS}

\section{Countries of Origin and types of IFDI}

Table 3 shows that, between 1983 and 2010, Wales received 1,668 inbound FDI projects, including 580 (34.7\%) new, 820 (49.2\%) expansionary, 236 (14.1\%) M\&A-based and 32 $(1.9 \%) \mathrm{JV}$-related investments.

Table 3 here

MNES based in a wide range of foreign countries committed new IFDI to Wales between 1983 and 2010, led by Europe as a whole, the US, Japan and Canada, which collectively contributed almost $80 \%$ of these flows (see Table 3). ${ }^{\text {iv }}$ Eighteen European countries contributed new IFDI, with $53.5 \%$ of this contribution coming from Germany, Ireland and France. The pre-eminence of IFDI from all developed countries of origin appears to have weakened over time, declining from 148 out of 178 new projects (83.1\%) between 1983 and 1989, to 171 of 226 new projects (75.7\%) from 2000 -2010. Emerging market countries such as China and India have, in contrast played a growing part in new IFDI, since $76 \%$ of IFDI from these countries occurred after 2000.

Turning to expansionary IFDI, Table 3 shows that inflows into Wales were led by the US, Europe, Japan and Canada, which together accounted for over $95 \%$ of these projects between 1983 and 2010. US MNEs came first with 318 expansionary projects, whilst Germany, France and Ireland led European expansionary investment, with 161 projects (54.4\% of the 
European total) between them. Japan committed 138 expansionary projects to Wales, and its contribution to such projects has grown numerically over time, underlining its MNEs' apparent preference for this type of inward investment (see Table 3).

Entry into Wales via the M\&A route was again dominated by Europe, the US, Canada and Japan, which jointly accounted for $92.3 \%$ of such IFDI between 1983 and 2010 (see Table 3) and $84.2 \%$ from 2000-2010. Within Europe, Germany, France and Ireland once more led the field, providing 42 of the 112 European projects (37.5\%) committed to Wales between 1983 and 2010. These countries contributed 55.6\% of their total M\&A projects between 2000 and 2010, thus strengthening their relative position. The US fell a little behind Europe in M\&Arelated IFDI terms (contributing 16.2\% of IFDI over 1983-2010) while Japan only provided $11.4 \%$ of such IFDI during these years.

The US, Canada, Japan and Europe accounted for almost $82 \%$ of the $J V$ projects committed to Wales between 1983 and 2010 (as Table 3 shows). However, JVs accounted for less than $5 \%$ of total inbound IFDI committed by major countries over this time. ${ }^{\mathrm{v}}$ This paucity of data has, therefore made it impossible to examine the links between JVs, job creation or safeguarding at the individual country of origin level by cross tabulation and correlation, or in the related discussion in this paper.

Table 3 can be used to analyse the relative importance of different types of IFDI to Wales from leading countries of origin. New IFDI, in the first place contributed proportionately more to total Canadian and European inward investment, relative to the US or Japan. Conversely, Japanese and US MNEs focused more on expansionary IFDI than these other two leading countries. The US and Europe, led the way in the relative importance of their 
M\&A IFDI to Wales, although they fell behind Canada and Japan as regards JV IFDI. Emerging market MNEs (such as China) appeared more likely to engage in new, as opposed to other forms of IFDI, reflecting their relatively late arrival in Wales

Job creation, safeguarding and capital investment

Tables $4 \mathrm{a}$ and $4 \mathrm{~b}$ show the relationships between types of IFDI and the creation and safeguarding of jobs in Wales for the leading countries of origin over the period 1983-2010. These employment effects were found to differ between types of inward investment, with the greatest number of new jobs being created by new and expansionary IFDI, and the greatest number of safeguarded jobs being provided by expansionary, followed (at a distance) by M\&A-related IFDI. In overall terms, expansionary IFDI created by far the greatest employment effects (55.6\%), followed by new (30\%), M\&A (12.5\%) and JV-related IFDI $(1.8 \%)$ in turn.

\section{Tables 4a and $4 \mathrm{~b}$ here}

Table 4a shows that US MNEs made the largest contribution to total new job creation (column 6) through all types of IFDI between 1983 and 2010, followed by those from Europe, Japan and Canada. New IFDI resulted in the greatest proportionate new job creation effects from Canadian and European MNE, whereas expansionary IFDI delivered the greatest effects for Japan and the US. Of the 54,675 new jobs created by new IFDI in Wales, 16,528 (30.2\%) came from the US, 2,246 (4.1\%) from Canada, 5334 (9.8\%) from Japan, and 16,978 (31.1\%) from Europe. Within the European total, Germany contributed 5,188 (30.6\%), followed by France, 2,491 (14.7\%) and Ireland, 5,012 (29.5\%). Amongst the 50,071 new 
jobs created by expansionary IFDI, the US was again the main provider (in absolute terms), followed by Europe and Japan. These three countries together provided $93.4 \%$ of the new jobs created through expansionary IFDI in Wales. Of the new jobs created by M\&A-related IFDI, the US provided 52.9\%, whilst Japan was the biggest contributor of new jobs through JV IFDI (46.8\%).

US MNEs led the way in total jobs safeguarded by all types of IFDI, followed by those based in Europe, Japan and Canada (see Table 4b). All made their greatest proportionate contributions to the safeguarding of jobs by expansionary IFDI (with this dominance being particularly marked for Japan), followed by M\&A-related IFDI. The same pattern was reflected in the proportionate contributions to jobs safeguarded made by the leading European countries, France, Germany and Ireland.

Taking all countries of origin together, almost $73 \%$ of safeguarded jobs related to expansionary IFDI, with over $23 \%$ being connected to M\&A IFDI. These two types of inward investment therefore provided over $96 \%$ of all jobs safeguarded by IFDI in Wales. The US and Europe were dominant, together providing $81 \%$ of the jobs safeguarded through expansionary IFDI, whilst also contributing $79 \%$ of the jobs safeguarded by means of M\&A IFDI.

Table $4 \mathrm{c}$ shows that a total of $£ 15,302.72 \mathrm{~m}$ was committed to Wales by way of capital expenditure on IFDI between 1983 and 2010. Of this total sum, new IFDI project-related investment contributed 39\%; expansionary IFDI, $42.1 \%$; M\&A projects, $16.4 \%$; and JVs 2.5\%. Behind the aggregate data, year-on-year capital expenditure on IFDI projects in 
Wales ranged between $£ 26 \mathrm{~m}$ to $£ 1765.83 \mathrm{~m}$ for new capital investment, to $£ 36$ to $£ 835$ for expansionary investment, $£ 0$ to $£ 354 \mathrm{~m}$ for M\&A investment, and $£ 0$ to $46.48 \mathrm{~m}$ for JV IFDI.

\section{Table 4c here}

From the country of origin perspective, the US provided $41.9 \%$ of the total IFDI-related capital investment of all types committed to Wales, followed by Europe with 23.8\%, Japan 12.2\% and Canada, 1.7\% over the period 1983-2010. Within Europe, Germany (28.1\%) and France $(20.2 \%)$ made up almost fifty percent of total capital flows.

Differences can be seen regarding the relative importance of each type of IFDI to capital flows into Wales for each country of origin. The majority of Canada's IFDI-related capital expenditure came from expansionary and new IFDI, with far smaller amounts being linked to M\&A and JV IFDI. A similar pattern was detected for both Japan and Europe. The US, however had a more balanced distribution of capital IFDI expenditure, devoting almost $40 \%$ to expansionary FDI, $31.2 \%$ to M\&A activity and $25 \%$ to new IFDI.

IFDI-related capital expenditures within Europe also showed differences by country, with. $63 \%$ of Germany's expenditure linked to new IFDI, whilst over $80 \%$ of that from France was associated with expansionary FDI. Ireland's late arrival as a donor of IFDI to Wales was reflected in its greater bias towards new IFDI- related capital expenditure (over 73\%), equivalent to approximately twice the average for Europe as a whole. For European MNEs, however JV -related capital expenditure was of little importance. 
Countries of origin, types of IFDI and employment effects

Table 5 shows the aggregate relationship estimated between types of project and their employment effects over the period 1983-2010). The Pearson Chi Squared values indicate that larger new IFDI projects were significantly related to greater new job creation, and the same was true for JV IFDI. Larger expansionary projects were found to be strongly positively and significantly related to both new and safeguarded jobs with the strength of this relationship being stronger for the latter. There was an insignificant but positive relationship between M\&A projects, new and safeguarded jobs.

\section{Table 5 here}

Table 6 indicates the association found between new projects, countries of origin and employment for the period $1983-2010 .{ }^{\text {vi }}$ Once again significant positive relationships were found to exist between new projects and new jobs created for all main providers, being particularly strong for new projects originating from Canada, Germany and France.

Table 7 summarises the association between expansionary projects, countries of origin and employment. The relationship between expansionary IFDI and new jobs created was strong and positive for all major source countries apart from Japan and France, being particularly strong for Canada and Germany. The impact on jobs safeguarded was somewhat different, however with only Japan showing an (insignificant) relationship between size of expansionary projects and jobs safeguarded. . ${ }^{\text {vii }}$ 
Table 8 shows the association found between $M \& A$-related IFDI projects, jobs created and jobs safeguarded for those countries for which there were sufficient data available. The crosstabulations shown in the table are confined to the US and Europe only, which together accounted for $86 \%$ of M\&A IFDI to Wales from 1983-2010. (The findings showed significant and positive relationships between M\&A projects, new and safeguarded jobs for both of these countries, with larger M\&A projects being associated with greater numbers of both new and safeguarded jobs. ${ }^{\text {viii }}$ Interestingly however, this relationship was stronger for Europe than for the US.

Tables 6, $7 \& 8$ here

IFDI-related capital investment, projects and employment effects

Table 9 summarises the relationship found between capital expenditure related to all IFDI projects, irrespective of countries of origin, making use of correlation analysis. A significant, positive relationship (estimated using a Pearson correlation two-tailed test), was found to exist between capital expenditure on new IFDI projects and new jobs created, capital expenditure on expansionary projects, and new and safeguarded jobs. But neither M\&A nor JV-related capital expenditure was significantly correlated with either new or safeguarded jobs. In the case of M\&A-related expenditure, these findings support those reported in Table 5, suggesting that M\&A-related inward investment has a less significant impact than new and expansionary IFDI on new job creation and the safeguarding of existing jobs in Wales.

Table 9 here 
Table 10 indicates that a strong and significant relationship exists between capital expenditure and new project-related job creation for MNEs from all leading countries of origin, apart from Ireland (reflecting the findings reported in Table 8). The case of Ireland for which a positive, but not significant relationship was established - might be explained by the fact that its MNEs were relatively late contributors to IFDI in Wales (UKTI, 2015), whilst many of its investments have also been small, thus generating few, if any new jobs.

Table 11 shows the relationship found between capital expenditure on expansionary projects, countries of origin and numbers of new and safeguarded jobs thereby created or secured. The results indicate (consistent with Table 9) that greater capital expenditure on such projects is significantly related to greater new job creation in Wales (for all countries other than Canada and France). The influence of increased capital investment on safeguarded jobs was even more consistently found (again echoing Table 9) for all countries other than Germany

The relationship between M\&A -related capital expenditure, countries of origin and employment in Wales is more difficult to discern, owing mainly perhaps to the smaller number and value of M\&A projects. Only the US and Europe committed substantial levels of M\&A-related IFDI to Wales. For the US, Table 12 confirms (consistently with Table 9) that no statistically significant relationship exists between capital expenditure on M\&A projects and new or safeguarded jobs. In the case of Europe, however a significant and positive relationship was found between M\&A-related investment and safeguarded jobs.

Tables 10, 11 and 12 here 


\section{CONCLUSIONS}

\section{Discussion}

This paper has examined the linkages that exist between IFDI and employment, and the resultant implications for government policy in Wales, a peripheral region of the UK. This analysis has been carried out against the background of official reports (Cardiff Business School, 2012; UKTI, 2012; Welsh Affairs Committee, 2012), which show that Wales' performance as a magnet for inward investment deteriorated between 2003 and 2010, reflected in its substantially reduced share of the UK's new IFDI projects and related jobs.

The findings reported in Tables 3-4c indicate that inward investment into Wales continues to be dominated by four main, developed countries / groups of countries, including the US, Europe, Japan and Canada (with Germany, France and Ireland being the leading contributors of IFDI from Europe). However their relative importance to Welsh IFDI has been changing over time as the contribution made by the US and Japanese MNEs has fallen whilst that from MNEs based in new source countries such as Ireland has risen. MNEs based in emerging market countries are also becoming increasingly important contributors to Welsh IFDI, although they remain insignificant, compared to developed country players.

Taking all countries of origin together, new and expansionary IFDI projects are most important for employment in Wales, contributing far more to job-creation and safeguarding than other types of inward investment. Both new and expansionary projects contribute significantly to the creation of new regional jobs, whilst expansionary IFDI has by far the greatest impact on job safeguarding. M\&A-related projects play a far lesser role in both 
respects, whilst the impact of JV FDI is even more minor. Capital expenditure on both new and expansionary based IFDI projects is linked to important new job creation and (in the latter case) to job safeguarding effects, whereas expenditure on M\&A and JV projects seem unlikely either to create or safeguard many jobs in Wales.

The more detailed (cross-tabulation and correlation-based) findings reported in Tables 5-12 provide support for these initial conclusions, together with additional understanding of the relative contributions made to Welsh employment by MNEs from different countries of origin. They confirm that larger new and expansionary IFDI projects were significantly and positively related to greater new job creation over the period from 1983-2013, whereas only expansionary projects were related to safeguarded jobs. They go on to suggest that the relatively small number of JV-related projects in Wales were also significantly and positively linked with new job creation, although not with safeguarded jobs. ${ }^{\mathrm{ix}}$

Focusing on country of origin effects, significant, positive relationships were found to exist between the scale of new projects and the numbers of new jobs created for all main source countries, (most strongly in the case of Canada, Germany and France). Significant and positive relationships were found between expansionary IFDI and new jobs created for all countries (other than Japan and France); and between such IFDI and jobs safeguarded for all apart from Japan. Similar relationships were also identified between M\&A projects, new and safeguarded jobs for the US and Europe, with larger M\&A projects being associated with greater numbers of both new and safeguarded jobs. ${ }^{\mathrm{x}}$

Turning to the issue of IFDI-related capital expenditure, the findings indicate that growing expenditure on new and expansionary projects was associated with increased new job 
creation, whereas only rising expenditure on expansionary projects was linked with increasing numbers of safeguarded jobs. From the country of origin perspective, they point to the existence of a connection between greater capital expenditure on new projects and greater new job creation for all source countries apart from Ireland. They also show that greater capital expenditure on expansionary IFDI projects was significantly related to a greater number of new jobs (for all countries other than Canada and France), and to safeguarded jobs (for Germany). Finally, a relationship was found between greater levels of M\&A activity and greater numbers of jobs safeguarded only for Europe as a whole.

\section{Policy implications}

These findings suggest a number of implications for inward investment policy development in Wales and in particular, for the targeting of IFDI on a country of origin basis. There is an apparent need to prioritise securing IFDI projects and related capital expenditure from established MNE investors (including the US, Canada, Japan and the leading European countries), since they are clearly continuing to make by far the largest contribution to job creation and safeguarding in Wales. If the creation of new jobs is the major priority, then new, expansionary (and possibly also JV-related) IFDI from these countries of origin should be targeted (with capital expenditure on new and expansionary projects being promoted by substantial investment incentives). If the safeguarding of existing jobs is the main concern, then the targeting of expansionary IFDI (and the promotion of related capital expenditure) would be by far the better policy.

The inward investment strategy preferences of developed economy-based MNEs and their employment consequences should also be taken into account when fine-tuning Wales' IFDI 
targeting strategy. Japan, for example carries out a high proportion of its inward investment through expansionary IFDI, associated with its highest levels of related job creation and safeguarding in the region between 1983 and 2010. Yet if more new inward investment could be attracted in future from this country's MNEs, the findings suggest that this could now be more productive in regional employment terms. In the case of US MNEs however, attracting expansionary projects would continue to make the greatest sense, since these would lead to significant levels of job creation and safeguarding for Wales

Welsh policy makers will also need to consider targeting IFDI from MNEs based in leading emerging market countries of origin such as China and India, from which inward investment to UK and its regions is now growing rapidly (UKTI, 2015). Whilst IFDI from developed countries should still receive the greater priority, the attraction of leading emerging marketbased MNEs could help to develop a more balanced portfolio of inward investment, facilitating the sustainability of Welsh IFDI related employment generation.

\section{Future research}

This research could now be taken further by examining inward Welsh inward investment in relation to specific time periods, in order to focus on the changing contribution of MNEs from particular countries of origin (such as the US and Japan) to job creation and safeguarding per Pound Sterling of IFDI-related capital expenditure. A more complete study of worldwide IFDI flows into Wales and their employment effects could also be undertaken, making use of published data and company case study findings to help provide more foresight on which countries of origin could most profitably be targeted by the Welsh inward investment authorities in future. A related study could also be carried out into the sectoral 
pattern of IFDI into Wales, focusing on the varying employment impact of inward investment flows which are channelled into different sectors of the Welsh economy. Both studies could be designed to include a longitudinal element, enabling the impact of varying countries of origin and sectors of destination for IFDI on regional employment to be identified and analysed.

In addition, the reasons underlying the declining competitiveness of Wales from the UK inward investment perspective would merit further research. A more detailed investigation of the reasons underlying the decline in Wales' ranking as a destination for IFDI (in relation to both the UK as a whole and other peripheral regions) would provide potentially valuable information for academics and practitioners alike, helping them to identify the economic and institutional changes that need to be made, in order to maximise the region's future attraction of IFDI and related employment benefits. 


\section{REFERENCES}

ACCOLLEY, D. (2003) The determinants and impacts of foreign direct investment, MPRA Paper Nr. 3084, 2007, Munich

ADAMS, J., ROBINSON, P. and VIGOR, A. (2003) A New Regional Policy for the UK. Institute for Public Policy Research North, Newcastle, UK.

ALMOND, P, FERNER, A and TREGASKIS O. (2015) The changing context of regional governance of FDI in England, European Urban and Regional Studies, 22.1, 61-76.

ASHCROFT, B. and LOVE, J. H. (1993) Takeovers, mergers and the regional economy. Edinburgh: Edinburgh University Press

BAILEY, D and DRIFFIELD N (2002) Hymer and uneven development revisited: Foreign direct investment and regional inequalities." Contributions to Political Economy 21.1, 55-68.

BIS (2011) Annual Business Inquiry. Northern Ireland Census of Employment and Quarterly Employment Survey, DETINI, Department of Business Innovation and Skills, London.

BIS (2013) Regional Economic Performance Indicators September 2012. Department for Business, Innovation and Skills, London.

BLOMSTRÖM, M., KOKKO A, and MUCCHIELLI J.L. (2003), The Economics of Foreign Direct Investment Incentives. Springer Berlin Heidelberg, 2003. 
BRAND, S., HILL, S. and MUNDAY M. (2000), Assessing the impacts of foreign manufacturing on regional economies: the cases of Wales, Scotland and the West Midlands, Regional Studies, 34.4, 343-355.

BROUTHERS, K.D. and BROUTHERS, L.E. (2003) Why service and manufacturing entry mode choices differ: the influence of transaction cost factors, risk and trust, Journal of Management Studies, 40.5, 1179-1204.

BROWN R and RAINES P. (2000), The Changing Nature of Foreign Investment Policy in Europe: From Promotion to Management. In: Dunning J (ed.), Regions Globalization and the Knowledge Based Economy. Oxford University Press, Oxford, UK.

CARDIFF BUSINESS SCHOOL (2012), Selling Wales: the role of agencies in attracting inward investment, Cardiff: Cardiff Business School and Cardiff Business Partnership.

CARDIFF CITY COUNCIL (2013) Inward Investment Report, Economy and Culture Scrutiny Committee, $10^{\text {th }}$ January.

CRINO R. (2009) Offshoring, multinationals and the labour market: a review of the empirical literature, Journal of Economic Surveys, 23.2, 197-249.

CRISCUOLO C and MARTIN R (2008) Longitudinal Micro Data Study of Regional Selective Assistance in Wales, Centre for Economic Performance, London School of Economics. 
DAWLEY, S (2007) Making labour-market geographies: volatile `flagship' inward investment and peripheral regions, Environment and Planning A, 39.6, 1403 - 1419

DE BACKER, K, and SLEUWAEGEN L. (2003) Does foreign direct investment crowd out domestic entrepreneurship? Review of Industrial Organization, 22.1, 67-84.

DRIFFIELD N. (1999) Indirect Employment Effects of Foreign Direct Investment Into the UK, Bulletin of Economic Research, 51.3, 207-222.

DRIFFIELD, N. (2004) Regional policy and spillovers from FDI in the UK." The Annals of Regional Science, 38.4, 579-594.

DRIFFIELD N and HUGHES D. (2003) Foreign and domestic investment: regional development or crowding out? Regional Studies, 37.3, 277-288.

DRIFFIELD N and MUNDAY M (2000) Industrial performance, agglomeration and foreign manufacturing investment in the UK, Journal of International Business Studies, 31.1, 21-37.

DRIFFIELD N. and TAYLOR, K. (2000), FDI and the labour market: a review of the evidence and policy implications, Oxford Review of Economic Policy, 16.3, 90-103.

DUNNING, J. H. (2000) Regions, globalization, and the knowledge economy. Oxford, UK: Oxford University Press

EVANS, P, HOLZ, R. and ROBERTS, A (2008) Empirical Investigation of Foreign Direct 
Investment in Wales, Welsh Assembly Government, Economic Research Unit, Cardiff, UK.

ERNST and YOUNG (2013), UK attractiveness survey. Ernst and Young, London. Online at: http://www.ey.com/UK/en/Issues/Business-environment/2013-UK-attractiveness-survey.

FDI MARKETS (2012) UK regional FDI statistics throw up a few surprises. Online at: www.fdiintelligence.com/Locations/Europe. Accessed: 13th June, 2013.

GARSON, G.D. (2013) Crosstabulation. Blue Book Series 13, Statistical Associates Publishers.

GHASEMI, A and ZAHEDIAS, S (2012) Normality Tests for Statistical Analysis: A Guide for Non-Statisticians, International Journal of Endocrinology and Metabolism, Spring, 10.2, 4686-489.

GIRMA, S., GREENAWAY D. and WAKELIN K. (2001), Who benefits from foreign, direct investment in the UK? Scottish Journal of Political Economy, 48.2, 119-133

GROSSE, R and TREVINO L.J. (1996), Foreign direct investment in the United States: an analysis by country of origin, Journal of International Business Studies, 27.1, 139-155.

GUIMARAES, P., FIGUEIREDO, O. and WOODWARD D. (2000). Agglomeration and the location of foreign direct investment in Portugal, Journal of Urban Economics, 47.1, 115135. 
HALKIER, H., DANSON M. and DAMBORG C (eds.) (2002) Regional development agencies in Europe, Vol. 21. Psychology Press.

HARDING, T. and JAVORCIK B. (2011) Roll out the Red Carpet and They Will Come: Investment Promotion and FDI Inflows, Economic Journal 121.557, 1445-1476.

HEJAZI W and PAULY P (2003) Motivations for FDI and Domestic Capital Formation, Journal of International Business Studies, 34.3, 282-289.

HOUSE OF COMMONS (2012) Inward Investment in Wales, Eighth Report of Session 2010-12, Welsh Affairs Committee.

JONES, J. and WREN, C. (2004), Do Inward Investors Achieve their Job Targets? Oxford Bulletin of Economics and Statistics, 66.4, 483-513.

KOTTARIDI, C. (2005), The core-periphery pattern of FDI-led growth and production structure in the EU, Applied Economics, 37.1, 99-113.

KRUGMAN, P. (1991) Increasing returns and economic geography, Journal of Political Economy, 99.3, 483-99.

LIM S-H (2008), How investment promotion affects attracting foreign direct investment: Analytical argument and empirical analyses, International Business Review, 17.1, 39-53: 
LIPSEY, R.E. (2004) Home-and host-country effects of foreign direct investment.

Challenges to globalization: Analyzing the economics. University of Chicago Press, 333-382.

LOEWENDAHL H.B. (2001) A framework for FDI promotion, Transnational Corporations, 10.1,1-42.

LOVERING J. (2003) MNCs and wannabes- Inward investment, discourses of regional development, and the regional service class. In: The New Competition for Inward Investment: Companies, Institutions and Territorial Development Eds. N Phelps, P Raines (Edward Elgar, Cheltenham, Glos), 137-155

MACKINNON D. and PHELPS N.A. (2001), Regional governance and foreign direct investment: the dynamics of institutional change in Wales and North East England, Geoforum, 32.2, 255-269

MAKINO, S. and NEUPERT K.E. (2000) National culture, transaction costs, and the choice between joint venture and wholly owned subsidiary, Journal of International Business Studies, 31.4, 705-713.

MARELLI, E., RESMINI L and SIGNORELLI M. (2014) The Effects of Inward FDI on Regional Employment in Europe, Romanian Journal of Regional Science, 8.1, 1-23.

McCORMICK, K. and SALCEDO, J (2015), SPSS for Dummies, John Wiley and Sons. 
McDONALD F, TÜSELMANN H J, HEISE A, WILLIAMS D, (2003) Employment in host regions and foreign direct investment, Environment and Planning C: Government and Policy, 21.5, $687-701$.

McGREGOR P.G. and SWALES, J.K. (2005), the economics of devolution/decentralisation in the UK: Some questions and answers, Regional Studies, 39.4, 477-494.

MIŠKINIS A, and BYRKA M (2014), The role of investment promotion agencies in attracting foreign direct investment, Ekonomika, 93.4, 41-57.

MORGAN, K. (2007) The learning region: institutions, innovation and regional renewal, Regional Studies, 41.S1, S147-S159.

MUNDAY, M, ROBERTS, A, and ROCHE, N. (2009) A Review of the Economic Evidence on the determinants and effects of foreign direct investment. Welsh Economy Research Unit, Cardiff, UK.

NAVARETTI, G. B. and VENABLES, A. (2004). Multinational firms in the world Economy, Princeton: Princeton University Press.

OFFICE FOR NATIONAL STATISTICS (2011) Regional Trends Online Tables, June.

Online at: http://www.statistics.gov.uk/downloada/Regional_Trends_39/12.05xls.

PAVLÍNEK, P (2004) Regional development implications of foreign direct investment in Central Europe, European Urban and Regional Studies 11.1, 47-70. 
PHELPS N, MACKINNON D, STONE I and BRAIDFORD P (2003) Embedding the multinationals? Institutions and the development of overseas manufacturing affiliates in Wales and North East England, Regional Studies, 37.1, 27-40

PORTER, M.E. (2003) The Economic Performance of Regions, Regional Studies, 37.6-7, 459-578.

RAMSAY N (2012) Destination Cymru- A Vision for Inward Investment and Investor Aftercare, Welsh Conservative Group, National Assembly for Wales, April.

REUER, J. J., and LEIBLEIN M. J. (2000) Downside risk implications of multinationality and international joint ventures, Academy of Management Journal, 43.2, 203-214.

REUS, T.H. and LAMONT B.T. (2009) The double-edged sword of cultural distance in international acquisitions, Journal of International Business Studies, 40.8, 1298-1316.

ROSE, S., SPINKS, N. and CANHOTO, A.I. (2015) Management Research: Applying the Principles, Routledge.

ROWTHORN, R. (2010), Combined and Uneven Development: Reflections on the NorthSouth Divide, Spatial Economic Analysis 5.4, 363-388. 
SCOTTISH GOVERNMENT (2000), Locate in Scotland Annual. Online at: http://www.scotland.gov.uk/News/Releases/2000/06/b4bad719-b15f-4fff-b5b6$602 \mathrm{cb} 8 \mathrm{e} 429 \mathrm{fd}$.

THOMAS, D. (1996) Winner or loser in the new Europe? Regional funding, inward investment and prospects for the Welsh economy, European Urban and Regional Studies, 3.3, 225-240.

THOMAS D.E and GROSSE, R. (2001), Country-of-origin determinants of foreign direct investment in an emerging market: the case of Mexico, Journal of International Management, 7.1, 59-79,

TIHANYI, L., GRIFFITH D.A., and RUSSELL C.J. (2005) The effect of cultural distance on entry mode choice, international diversification, and MNE performance: A meta-analysis, Journal of International Business Studies, 36.3, 270-283.

UK TRADE AND INVESTMENT (2015) Great Britain and Northern Ireland Inward Investment Report, 2014-15. London, UK.

WELSH AFFAIRS COMMITTEE (2012) Inward Investment in Wales, Eighth Report, House of Commons, London.

WILLIAMS, D. (2003), Explaining employment changes in foreign manufacturing investment in the UK, International Business Review 12.4, 479-497. 
WREN C and TAYLOR J. (1999) Industrial Restructuring and Regional Policy, Oxford Economic Papers, 51.3, 487-516.

YAMAWAKI, H. (1994) Entry patterns of Japanese multinationals in US and European manufacturing. In M. Mason, and D. Encarnation (Eds.), Does ownership matter? Japanese multinationals in Europe. Oxford: Oxford University Press.

YOUNG, S., HOOD N, and WILSON A. (1994) Targeting policy as a competitive strategy for European inward investment agencies, European Urban and Regional Studies, 1.2, 143159. 


\begin{abstract}
${ }^{i}$ New IFDI could lead to safeguarded jobs, where, for example new, production line investment results in the abandonment of formerly planned job losses, linked to the previously intended outsourcing of finance team operations currently located in house, in an existing foreign subsidiary. However we could find no significant association between new IFDI and safeguarded jobs for Wales (see Tables 5 and 9).

ii There were 580 items of data for new capital inward investments, 820 expansionary inward investments and 236 M\&A-related inward investments into Wales between 1983 and March 2010, providing a large data base suited to correlation analysis, enhancing the overall validity of the resultant findings.
\end{abstract}

iii To test for normality, the Shapiro-Wilks test was used in SPSS for each variable, since the sample for each variable was less than 2000. A p-value in excess of 0.05 was obtained, enabling us to reject the alternative hypothesis and to conclude that our data came from a normal distribution.

${ }^{\text {iv }}$ On an individual country level, WAG data showed that Japan was the second most important inward investor in Wales between 1983 and 2010, with considerably greater levels of total IFDI projects than Germany or France.

${ }^{\mathrm{v}}$ The figures in brackets indicate the proportion of the investments falling into each category for each country

${ }^{\mathrm{vi}} \mathrm{No}$ analysis of jobs safeguarded is provided due to paucity of data.

vii This may possibly indicate that Japanese expansionary investment is typically more technologically focused than for the other leading source countries, leading to only limited increases in jobs following such IFDI. However, testing any such hypothesis would require further exploration of the data at a more highly disaggregated level.

${ }^{\text {viii }}$ M\&A projects could be expected perhaps to have a greater impact on safeguarded jobs by ensuring the survival of existing Welsh businesses post-absorption or takeover, although new job creation may thereafter also occur.

${ }^{\mathrm{ix}} \mathrm{M} \& \mathrm{~A}$ projects were not however significantly related to job creation or safeguarding.

${ }^{\mathrm{x}}$ No statistically significant relationship was found for JV projects 
Table 1: Economic characteristics of Wales compared to Scotland, South East England and the UK as a whole

\begin{tabular}{|c|c|c|c|c|}
\hline & Wales & Scotland & $\begin{array}{l}\text { South East } \\
\text { England }\end{array}$ & UK \\
\hline (1) Population 2011 (thousands) & 3,064 & 5,255 & 8,653 & 63,233 \\
\hline $\begin{array}{l}\text { (2) Gross value added (GVA), } \\
\text { current basic prices (£million, } \\
2010 \text { ) }\end{array}$ & 45,334 & 105,590 & 186,860 & $1,301,118$ \\
\hline $\begin{array}{l}\text { (3) GVA per capita (UK index, } \\
\text { 2010) }\end{array}$ & 74.0 & 99.3 & 107.1 & 100 \\
\hline $\begin{array}{l}\text { (4) Value of Exports of Goods } \\
\text { (Percentage of Regional } \\
\text { GVA, 2011) }\end{array}$ & 28.1 & 15.6 & 21.8 & 21.5 \\
\hline $\begin{array}{l}\text { (5) Labour productivity } \\
\text { (Nominal GVA per hour worked } \\
\text { index, 2010) }\end{array}$ & 84.6 & 100 & 107.2 & 100 \\
\hline $\begin{array}{l}\text { (6) Median full time hourly } \\
\text { earnings (all industries and } \\
\text { services, } £ \text { per hour, 2011) }\end{array}$ & 11.50 & 12.42 & 13.41 & 12.71 \\
\hline $\begin{array}{l}\text { (7) Gross disposable income per } \\
\text { capita (UK index, 2010) }\end{array}$ & 87.5 & 97.7 & 112 & 100 \\
\hline $\begin{array}{l}\text { (8) Unemployment rate, }(\mathrm{Q} 4 \text {, } \\
\text { 2011, percentages) }\end{array}$ & 8.9 & 8.6 & 6.4 & $\begin{array}{l}7.8 \\
\end{array}$ \\
\hline $\begin{array}{l}\text { (9) Percentage of working } \\
\text { population qualified to NQF level } \\
2 \text { or higher, 2010\# }\end{array}$ & 74.8 & 78.6 & 82.2 & 78.5 \\
\hline $\begin{array}{l}\text { (10) Gross domestic R\&D } \\
\text { spending as \% workplace GVA } \\
\text { (2010) }\end{array}$ & 1.2 & 1.8 & 3.0 & 2.0 \\
\hline $\begin{array}{l}\text { (11) New business start- ups per } \\
\text { 10,000 adult population (UK } \\
\text { index, 2010) }\end{array}$ & 65.5 & 77.5 & 115.6 & 100 \\
\hline $\begin{array}{l}\text { (12) Regional selective assistance } \\
\text { (Net Grant equivalent, end 2011) }\end{array}$ & $\begin{array}{l}35 \% \text { (West } \\
\text { Wales, } \\
\text { North West } \\
\text { Wales and } \\
\text { South } \\
\text { Wales } \\
\text { Valleys) }\end{array}$ & $\begin{array}{l}30 \% \\
\text { (Western } \\
\text { Highlands) } \\
20 \% \text { (West } \\
\text { Central } \\
\text { Lowlands) }\end{array}$ & $\begin{array}{l}15-20 \% \\
\text { (East Kent } \\
\text { only) }\end{array}$ & \\
\hline
\end{tabular}

Notes: \#Equivalent to 5 or more GCSE grades A*-C;

Source: BIS (2013); Criscuolo and Martin (2008); ONS (2011).

Table 2: $\quad$ Percentage of new inward investment projects won by UK regions 
(excluding London and South East), 2003-4 and 2009-10

\begin{tabular}{|c|c|c|c|c|c|c|}
\hline $\begin{array}{l}\text { Country and } \\
\text { Region }\end{array}$ & $\begin{array}{l}\mathrm{Nu} \\
\mathrm{IFD}\end{array}$ & $\begin{array}{l}\mathrm{r} \text { and } \mathrm{p} \\
\text { ojects }\end{array}$ & centa & of new & Ranking & \\
\hline & 200 & & 2009 & & $2003-4$ & 2009-10 \\
\hline Scotland & 69 & $8.5 \%$ & 146 & $9.0 \%$ & 1 & $1 \leftrightarrow$ \\
\hline North West & 53 & $6.5 \%$ & 110 & $6.8 \%$ & 3 & $2 \uparrow$ \\
\hline $\begin{array}{l}\text { West } \\
\text { Midlands }\end{array}$ & 37 & $4.5 \%$ & 81 & $5 \%$ & 4 & $3 \uparrow$ \\
\hline $\begin{array}{l}\text { Northern } \\
\text { Ireland }\end{array}$ & 33 & $4 \%$ & 70 & $4.3 \%$ & 5 & $4 \uparrow$ \\
\hline North East & 28 & $3.5 \%$ & 60 & $3.7 \%$ & 6 & $5 \uparrow$ \\
\hline $\begin{array}{l}\text { Yorks and } \\
\text { Humber }\end{array}$ & 16 & $2.0 \%$ & 60 & $3.7 \%$ & 9 & $6 \uparrow$ \\
\hline East Anglia & 20 & $2.5 \%$ & 60 & $3.7 \%$ & 8 & $7 \uparrow$ \\
\hline East Midlands & 28 & $3.5 \%$ & 57 & $3.5 \%$ & 8 & $8 \leftrightarrow$ \\
\hline Wales & 61 & $7.5 \%$ & 56 & $3.5 \%$ & 2 & $9 \downarrow$ \\
\hline South West & 24 & $3 \%$ & 53 & $3.3 \%$ & 6 & $10 \downarrow$ \\
\hline
\end{tabular}

Source: Authors' calculations, based on Cardiff Business School (2012) and UKTI (2015)

Table 3: Leading countries of origin for inbound FDI projects into Wales, 1983March 2010

\begin{tabular}{|l|l|l|l|l|l|}
\hline & New IFDI & $\begin{array}{l}\text { Expansionary } \\
\text { IFDI }\end{array}$ & $\begin{array}{l}\text { Merger \& } \\
\text { Acquisition } \\
\text { IFDI }\end{array}$ & $\begin{array}{l}\text { Joint Venture } \\
\text { IFDI }\end{array}$ & Total IFDI \\
\hline US & $143(25.4 \%)$ & $318(56.6 \%)$ & $91(16.2 \%)$ & $10(1.8 \%)$ & $562(100 \%)$ \\
\hline Canada & $28(40.0 \%)$ & $31(44.3 \%)$ & $8(11.4 \%)$ & $3(4.2 \%)$ & $70(100 \%)$ \\
\hline Japan & $51(25.1 \%)$ & $138(67.9 \%)$ & $7(3.4 \%)$ & $7(3.4 \%)$ & $203(100 \%)$ \\
\hline Europe & $241(36.8 \%)$ & $296(45.2 \%)$ & $112(17.1 \%)$ & $6(0.9 \%)$ & $655(100 \%)$ \\
\hline Of which: & & & & & \\
\hline Germany & $47(33.3 \%)$ & $77(54.6 \%)$ & $14(9.9 \%)$ & $3(2.1 \%)$ & $141(100 \%)$ \\
\hline France & $38(33.9 \%)$ & $55(49.1 \%)$ & $19(17.0 \%)$ & $0(0 \%)$ & $112(100 \%)$ \\
\hline Ireland & $44(53.7 \%)$ & $29(35.4 \%)$ & $9(11.0 \%)$ & $0(0 \%)$ & $82(100 \%)$ \\
\hline $\begin{array}{l}\text { Main } \\
\text { emerging } \\
\text { market } \\
\text { countries }\end{array}$ & $54(62.8 \%)$ & $18(20.9 \%)$ & $12(14.0 \%)$ & $2(2.3 \%)$ & $86(100 \%)$ \\
\hline China & $17(85.0 \%)$ & $2(20 \%)$ & $0(0 \%)$ & $1(10 \%)$ & $20(100 \%)$ \\
\hline India & $10(58.8 \%)$ & $4(23.5 \%)$ & $3(17.6 \%)$ & $0(0 \%)$ & $17((100 \%)$ \\
\hline Taiwan & $9(64.3 \%)$ & $4(28.6 \%)$ & $1(7.1 \%)$ & $0(0 \%)$ & $14(100 \%)$ \\
\hline Singapore & $6(66.7 \%)$ & $1(11.1 \%)$ & $2(22.2 \%)$ & $0(0 \%)$ & $9(100 \%)$ \\
\hline Hong Kong & $6(42.9 \%)$ & $5(35.7 \%)$ & $2(14.3 \%)$ & $1(7.1 \%)$ & $14(100 \%)$ \\
\hline South Africa & $6(50 \%)$ & $2(16.7 \%)$ & $4(33.3 \%)$ & $0(0 \%)$ & $12(100 \%)$ \\
\hline Total & $580(34.7 \%)$ & $820(49.2 \%)$ & $236(14.1 \%)$ & $32(1.9 \%)$ & $1,668(100 \%)$ \\
\hline
\end{tabular}


Source: Authors' calculations (analysis of WAG data)

Table 4a: New job creation via different types of IFDI into Wales, 1983-2010

\begin{tabular}{|l|l|l|l|l|l|}
\hline & New IFDI & $\begin{array}{l}\text { Expansionary } \\
\text { IFDI }\end{array}$ & $\begin{array}{l}\text { Merger \& } \\
\text { Acquisition } \\
\text { IFDI }\end{array}$ & $\begin{array}{l}\text { Joint Venture } \\
\text { IFDI }\end{array}$ & $\begin{array}{l}\text { Total New } \\
\text { Jobs }\end{array}$ \\
\hline US & $\begin{array}{l}16,528 \\
(44.7 \%)\end{array}$ & $\begin{array}{l}18,455 \\
(49.9 \%)\end{array}$ & $1,564(4.2 \%)$ & $413(1.1 \%)$ & $36,960(100 \%)$ \\
\hline Canada & $\begin{array}{l}2,246 \\
(51.8 \%)\end{array}$ & $\begin{array}{l}2,008 \\
(46.3 \%)\end{array}$ & $79(1.8 \%)$ & $2(0.05 \%)$ & $4,335(100 \%)$ \\
\hline Japan & $\begin{array}{l}5,334 \\
(26.8 \%)\end{array}$ & $\begin{array}{l}13,389 \\
(67.2 \%)\end{array}$ & $0(0 \%)$ & $1,207(6.1 \%)$ & $19,930(100 \%)$ \\
\hline Europe & $\begin{array}{l}16,978 \\
(51.5 \%)\end{array}$ & $\begin{array}{l}14,828 \\
(45.0 \%)\end{array}$ & $1,035(3.1 \%)$ & $129(0.4 \%)$ & $32,970(100 \%)$ \\
\hline Of which: & $\begin{array}{l}5,188 \\
(55.4 \%)\end{array}$ & $\begin{array}{l}4,079 \\
(43.5 \%)\end{array}$ & $4(0.05 \%)$ & $98(1.05 \%)$ & $9,369(100 \%)$ \\
\hline Germany & $\begin{array}{l}2,491 \\
(43.3 \%)\end{array}$ & $\begin{array}{l}3,222 \\
(56.0 \%)\end{array}$ & $40(0.7 \%)$ & $0(0 \%)$ & $5,753(100 \%)$ \\
\hline France & $\begin{array}{l}5,012 \\
(70.3 \%)\end{array}$ & $\begin{array}{l}1,982 \\
(27.8 \%)\end{array}$ & $138(1.9 \%)$ & $0(0 \%)$ & $7,132(100 \%)$ \\
\hline Ireland & $\begin{array}{l}54,675 \\
(49.6 \%)\end{array}$ & $\begin{array}{l}50,071 \\
(45.4 \%)\end{array}$ & $2,958(2.7 \%)$ & $2,579(2.3 \%)$ & $\begin{array}{l}110,283 \\
(100 \%)\end{array}$ \\
\hline $\begin{array}{l}\text { Total All } \\
\text { Countries }\end{array}$ & & & & \\
\hline
\end{tabular}

Source: Authors' calculations (analysis of WAG data)

Table 4b: Jobs safeguarded via different types of IFDI into Wales, 1983-2010

\begin{tabular}{|l|l|l|l|l|l|}
\hline & New IFDI & $\begin{array}{l}\text { Expansionary } \\
\text { IFDI }\end{array}$ & $\begin{array}{l}\text { Merger \& } \\
\text { Acquisition } \\
\text { IFDI }\end{array}$ & $\begin{array}{l}\text { Joint Venture } \\
\text { IFDI }\end{array}$ & Total \\
\hline US & $1,890(5.1 \%)$ & $\begin{array}{l}27,133 \\
(73.0 \%)\end{array}$ & $\begin{array}{l}7,699 \\
(20.7 \%)\end{array}$ & $450(1.2 \%)$ & $\begin{array}{l}37,172 \\
(100 \%)\end{array}$ \\
\hline Canada & $180(6.9 \%)$ & $\begin{array}{l}1,974 \\
(76.5 \%)\end{array}$ & $415(16.1 \%)$ & $11(0.4 \%)$ & $2,580(100 \%)$ \\
\hline Japan & $0(0 \%)$ & $\begin{array}{l}7,642 \\
(87.3 \%)\end{array}$ & $1073(12.3 \%)$ & $35(0.4 \%)$ & $8,750(100 \%)$ \\
\hline Europe & $250(1.0 \%)$ & $\begin{array}{l}17,492 \\
(72.6 \%)\end{array}$ & $\begin{array}{l}6,355 \\
(26.4 \%)\end{array}$ & $0(0 \%)$ & $\begin{array}{l}24,097 \\
(100 \%)\end{array}$ \\
\hline Of which: & & $\begin{array}{l}4,331 \\
(80.1 \%)\end{array}$ & $\begin{array}{l}1,078 \\
(19.9 \%)\end{array}$ & $0(0 \%)$ & $5,409(100 \%)$ \\
\hline Germany & $0(0 \%)$ & & & \\
\hline
\end{tabular}




\begin{tabular}{|l|l|l|l|l|l|}
\hline France & $0(0 \%)$ & $\begin{array}{l}4,962 \\
(75.2 \%)\end{array}$ & $\begin{array}{l}1,634 \\
(24.8 \%)\end{array}$ & $0(0 \%)$ & $6,596(100 \%)$ \\
\hline Ireland & $0(0 \%)$ & $846(82.3 \%)$ & $182(17.7 \%)$ & $0(0 \%)$ & $1,028(100 \%)$ \\
\hline Total All & $2,250(3.0 \%)$ & 55,258 & 17,711 & $727(1.0 \%)$ & 75,946 \\
Countries & & $(73.0 \%)$ & $(23.0 \%)$ & & $(100 \%)$ \\
\hline
\end{tabular}

Source: Authors' calculations (analysis of the WAG data)

Table 4c: $\quad$ Capital expenditure by main countries of origin (£million)

\begin{tabular}{|c|c|c|c|c|c|}
\hline & New FDI & $\begin{array}{l}\text { Expansionary } \\
\text { FDI }\end{array}$ & $\begin{array}{l}\text { Merger \& } \\
\text { Acquisition } \\
\text { FDI }\end{array}$ & $\begin{array}{l}\text { Joint } \\
\text { Venture FDI }\end{array}$ & Total \\
\hline US & $\begin{array}{l}1,599.69 \\
(25.0 \%)\end{array}$ & $\begin{array}{l}2,550.59 \\
(39.8 \%)\end{array}$ & $\begin{array}{l}1,998.64 \\
(31.2 \%)\end{array}$ & $258.9(4.0 \%)$ & $\begin{array}{l}6,407.82 \\
(100 \%)\end{array}$ \\
\hline Canada & $\begin{array}{l}101.89 \\
(40.2 \%)\end{array}$ & $\begin{array}{l}129.35 \\
(51.1 \%)\end{array}$ & $12.5(4.9 \%)$ & $9.42(3.7 \%)$ & $\begin{array}{l}253.16 \\
(100 \%)\end{array}$ \\
\hline Japan & $\begin{array}{l}563.83 \\
(30.2 \%)\end{array}$ & $\begin{array}{l}1,250.35 \\
(66.9 \%)\end{array}$ & $23.5(1.6 \%)$ & $30.65(1.6 \%)$ & $\begin{array}{l}1,868.33 \\
(100 \%)\end{array}$ \\
\hline Europe & $\begin{array}{l}1,380.13 \\
(37.9 \%)\end{array}$ & $\begin{array}{l}1,895.69 \\
(52.0 \%)\end{array}$ & $\begin{array}{l}363.06 \\
(10.0 \%)\end{array}$ & $5.7(0.16 \%)$ & $\begin{array}{l}3,644.58 \\
(100 \%)\end{array}$ \\
\hline \multicolumn{6}{|l|}{ Of which: } \\
\hline Germany & $\begin{array}{l}645.38 \\
(63.0 \%)\end{array}$ & $\begin{array}{l}363.03 \\
(35.4 \%)\end{array}$ & $13(1.3 \%)$ & $2.79(0.27 \%)$ & $\begin{array}{l}1,024.2 \\
(100 \%)\end{array}$ \\
\hline France & $\begin{array}{l}87.18 \\
(11.9 \%)\end{array}$ & $590.53(80.4 \%)$ & $56.9(7.7 \%)$ & $0(0 \%)$ & $\begin{array}{l}734.61 \\
(100 \%)\end{array}$ \\
\hline Ireland & $\begin{array}{l}343.77 \\
(73.4 \%)\end{array}$ & $93.49(20.0 \%)$ & $31.14(6.6 \%)$ & $0(0 \%)$ & $\begin{array}{l}468.4 \\
(100 \%)\end{array}$ \\
\hline $\begin{array}{l}\text { Total All } \\
\text { Countries }\end{array}$ & $\begin{array}{l}5,973.47 \\
(39.0 \%)\end{array}$ & $\begin{array}{l}6,440.2 \\
(42.1 \%)\end{array}$ & $\begin{array}{l}2,509.5 \\
(16.4 \%)\end{array}$ & $\begin{array}{l}379.55 \\
(2.5 \%)\end{array}$ & $\begin{array}{l}15,302.72 \\
(100 \%)\end{array}$ \\
\hline
\end{tabular}

Source: Authors' calculations (analysis of the WAG data)

Table 5: $\quad$ Cross tabulation relationship between types of project and employment in Wales

\begin{tabular}{|l|l|l|}
\hline & Number of new Jobs & Number of Safeguarded jobs \\
\hline Number of new projects & $11.163^{*}$ & 2.621 \\
\hline $\begin{array}{l}\text { Number of Expansionary } \\
\text { projects }\end{array}$ & $4.66^{*}$ & $10.177^{* * *}$ \\
\hline Number of M\&A projects & 4.339 & 3.824 \\
\hline
\end{tabular}




\begin{tabular}{|l|l|l|}
\hline Number of JV projects & $3.759^{* *}$ & \\
\hline
\end{tabular}

Notes: The figures in the table are the Pearson Chi Squared values

$*$ sig at $10 \%$ level, $* *$ sig at $5 \%$ level, $* * *$ sig at $1 \%$ level

Source: Authors' calculations

Table 6: Cross tabulations between main countries of origin, new projects and employment

\begin{tabular}{|l|l|}
\hline & $\begin{array}{l}\text { New jobs provided by new } \\
\text { projects, same country of } \\
\text { origin }\end{array}$ \\
\hline New projects from the US & $6.238^{* *}$ \\
\hline New projects from Japan & $4.492 * *$ \\
\hline New projects from Canada & $13.238^{* * *}$ \\
\hline New projects from Europe & $2.902 *$ \\
\hline New projects from Germany & $7.919 * * *$ \\
\hline New projects from France & $18.90 * * *$ \\
\hline New projects from Ireland & $5.891 * *$ \\
\hline
\end{tabular}

Notes: The figures in the table are the Pearson Chi Squared values

$*$ sig at $10 \%$ level, $* *$ sig at $5 \%$ level, ***sig at $1 \%$ level

Source: Authors' calculations

Table 7: Cross-tabulations between main countries of origin, expansionary projects and employment

\begin{tabular}{|l|l|l|}
\hline & $\begin{array}{l}\text { New jobs provided by } \\
\text { expansionary projects, same } \\
\text { country of origin }\end{array}$ & $\begin{array}{l}\text { Safeguarded jobs provided } \\
\text { by expansionary projects, } \\
\text { same country of origin }\end{array}$ \\
\hline
\end{tabular}




\begin{tabular}{|l|l|l|}
\hline $\begin{array}{l}\text { Expansionary projects from } \\
\text { the US }\end{array}$ & $7.348^{* *}$ & $4.747^{*}$ \\
\hline $\begin{array}{l}\text { Expansionary projects from } \\
\text { Japan }\end{array}$ & 2.229 & 0.175 \\
\hline $\begin{array}{l}\text { Expansionary projects from } \\
\text { Canada }\end{array}$ & $12.273^{* * *}$ & $12.273^{* * *}$ \\
\hline $\begin{array}{l}\text { Expansionary projects from } \\
\text { Europe }\end{array}$ & $16.989^{* * *}$ & $4.464^{* *}$ \\
\hline $\begin{array}{l}\text { Expansionary projects from } \\
\text { Germany }\end{array}$ & $15.963^{* * *}$ & $3.161^{*}$ \\
\hline $\begin{array}{l}\text { Expansionary projects from } \\
\text { France }\end{array}$ & 2.229 & $14.256^{* * *}$ \\
\hline $\begin{array}{l}\text { Expansionary projects from } \\
\text { Ireland }\end{array}$ & $5.067^{* *}$ & $5.185^{* *}$ \\
\hline
\end{tabular}

Notes: The figures in the table are the Pearson Chi Squared values

$*$ sig at $10 \%$ level, $* *$ sig at $5 \%$ level, $* * *$ sig at $1 \%$ level

Source: Authors' calculations

Table 8:

Cross-tabulations between main countries of origin, M\&A projects and employment

\begin{tabular}{|l|l|l|}
\hline & $\begin{array}{l}\text { New jobs provided by M\&A } \\
\text { projects, same country of } \\
\text { origin }\end{array}$ & $\begin{array}{l}\text { Safeguarded jobs provided } \\
\text { by M\&A projects, same } \\
\text { country of origin }\end{array}$ \\
\hline M\&A projects from the US & $3.161^{*}$ & $4.793 * *$ \\
\hline M\&A projects from Europe & $4.793 * *$ & $13.114 * * *$ \\
\hline
\end{tabular}

Notes: The figures in the table are the Pearson Chi Squared values

$*$ sig at $10 \%$ level, $* *$ sig at $5 \%$ level, ***sig at $1 \%$ level

Source: Authors' calculations 
Table 9:

Correlations between capital expenditure by project type and employment in Wales

\begin{tabular}{|l|l|l|}
\hline & Number of new jobs & Number of safeguarded jobs \\
\hline $\begin{array}{l}\text { Capital expenditure on new } \\
\text { projects }\end{array}$ & $0.565 * * *$ & 0.351 \\
\hline $\begin{array}{l}\text { Capital expenditure on } \\
\text { expansionary projects }\end{array}$ & $0.444 * * *$ & $0.289 * * *$ \\
\hline $\begin{array}{l}\text { Capital expenditure on M\&A } \\
\text { projects }\end{array}$ & 0.069 & -0.019 \\
\hline $\begin{array}{l}\text { Capital expenditure on JV } \\
\text { projects }\end{array}$ & 0.354 & 0.162 \\
\hline
\end{tabular}

Notes: ***sig at $1 \%$ level

Source: Authors' calculations

Table 10: Correlations between main countries of origin, new capital expenditure and jobs

\begin{tabular}{|l|l|}
\hline & $\begin{array}{l}\text { New jobs provided by new } \\
\text { projects }\end{array}$ \\
\hline $\begin{array}{l}\text { Capital expenditure on new } \\
\text { projects, US }\end{array}$ & $0.604 * * *$ \\
\hline $\begin{array}{l}\text { Capital expenditure on new } \\
\text { projects, Canada }\end{array}$ & $0.612 * * *$ \\
\hline $\begin{array}{l}\text { Capital expenditure on new } \\
\text { projects, Japan }\end{array}$ & $0.675 * * *$ \\
\hline $\begin{array}{l}\text { Capital expenditure on new } \\
\text { projects, Europe }\end{array}$ & $0.503 * * *$ \\
\hline $\begin{array}{l}\text { Capital expenditure on new } \\
\text { projects, France }\end{array}$ & $0.652 * * *$ \\
\hline
\end{tabular}




\begin{tabular}{|l|l|}
\hline $\begin{array}{l}\text { Capital expenditure on new } \\
\text { projects, Germany }\end{array}$ & $0.346^{* *}$ \\
\hline $\begin{array}{l}\text { Capital expenditure on new } \\
\text { projects, Ireland }\end{array}$ & 0.312 \\
\hline
\end{tabular}

Notes: ** sig at $5 \%$ level, $* * *$ sig at $1 \%$ level

Source: Authors' calculations

Table 11: Correlations between main countries of origin, expansionary capital expenditure and jobs

\begin{tabular}{|l|l|l|}
\hline & $\begin{array}{l}\text { New jobs provided by } \\
\text { expansionary projects }\end{array}$ & $\begin{array}{l}\text { Safeguarded jobs provided } \\
\text { by expansionary projects }\end{array}$ \\
\hline $\begin{array}{l}\text { Capital expenditure on } \\
\text { expansionary projects, US }\end{array}$ & $0.445^{* * *}$ & $0.283^{* * * *}$ \\
\hline $\begin{array}{l}\text { Capital expenditure on } \\
\text { expansionary projects, } \\
\text { Canada }\end{array}$ & 0.148 & $0.699^{* * *}$ \\
\hline $\begin{array}{l}\text { Capital expenditure on } \\
\text { expansionary projects, Japan }\end{array}$ & $0.553^{* * *}$ & $0.259^{* * *}$ \\
\hline $\begin{array}{l}\text { Capital expenditure on } \\
\text { expansionary projects, } \\
\text { Europe }\end{array}$ & $0.118^{* *}$ & $0.244^{* * *}$ \\
\hline $\begin{array}{l}\text { Capital expenditure on } \\
\text { expansionary projects, } \\
\text { France }\end{array}$ & 0.057 & $0.413^{* * *}$ \\
\hline $\begin{array}{l}\text { Capital expenditure on } \\
\text { expansionary projects, } \\
\text { Germany }\end{array}$ & $0.406^{* * *}$ & 0.198 \\
\hline $\begin{array}{l}\text { Capital expenditure on } \\
\text { expansionary projects, } \\
\text { Ireland }\end{array}$ & $0.409^{* *}$ & $0.833^{* * *}$ \\
\hline
\end{tabular}


Notes: $* *$ sig at $5 \%$ level, $* * *$ sig at $1 \%$ level

Source: Authors' calculations

Table 12: Correlations between main countries of origin for M\&A-related capital expenditure and employment

\begin{tabular}{|l|l|l|}
\hline & $\begin{array}{l}\text { New jobs provided by M\&A } \\
\text { projects }\end{array}$ & $\begin{array}{l}\text { Safeguarded jobs provided } \\
\text { by M\&A projects }\end{array}$ \\
\hline $\begin{array}{l}\text { Capital expenditure on M\&A } \\
\text { projects, US }\end{array}$ & 0.084 & -0.093 \\
\hline $\begin{array}{l}\text { Capital expenditure on M\&A } \\
\text { projects, Europe }\end{array}$ & -0.058 & $0.239 * *$ \\
\hline
\end{tabular}

Notes: $* *$ sig at $5 \%$ level

Source: Authors' calculations 